Revista Eletrônica de Direito Processual - REDP.

Rio de Janeiro. Ano 11. Volume 18. Número 2. Maio a Agosto de 2017

Periódico Quadrimestral da Pós-Graduação Stricto Sensu em Direito Processual da UERJ

Patrono: José Carlos Barbosa Moreira. ISSN 1982-7636. pp. 219-244

www.redp.uerj.br

\title{
O (B)ÔNUS ARGUMENTATIVO NECESSÁRIO À APLICAÇÃO DAS MEDIDAS EXECUTÓRIAS ATÍPICAS - NOTAS PARA UM INSTRUMENTALISMO \\ PROCESSUAL CONSTITUCIONALMENTE ADEQUADO ${ }^{1}$
}

\section{THE ARGUMENTATIVE (B)ONUS REQUIRED FOR THE APPLICATION OF ATYPICAL EXECUTORY MEASURES - NOTES FOR A CONSTITUCIONALLY SUITABLE INSTRUMENTAL PROCESS}

Guilherme Gonçalves Alcântara Pós-graduando em Direito Penal e Processo Penal. Advogado. Centro Universitário Toledo-Prudente, Presidente Prudente/SP. guilhermealcantara@msn.com

Daniel Colnago Rodrigues Mestrando em Direito Processual Civil pela USP. Professor de Direito Processual Civil do Centro Universitário Toledo Prudente, Presidente Prudente/SP. Professor do Curso de Pós-graduação em Direito Processual Civil do CERS. Advogado. danielcolnago@gmail.com

RESUMO: Exploração da relevância da fundamentação proporcional, íntegra e coerente como dever do magistrado na aplicação/interpretação dos incisos IV, do artigo 139 do Código de Processo Civil Brasileiro de 2015, que leva em consideração as soluções propostas pela Escola Analítica e a Crítica Hermenêutica do Direito.

PALAVRAS-CHAVE: Instrumentalismo processual, Fundamentação, Proporcionalidade, Coerência, Integridade.

\footnotetext{
${ }^{1}$ Artigo recebido em 20/12/2016 e aprovado em 22/06/2017.
} 
ABSTRACT: An exploration of the importance of proportional, fair and consistent reasoning as a magistrate of duty in the application/interpretation of the sections IV of Article 139 of the Brazilian Civil Procedure Code of 2015, which takes into consideration the solutions proposed by the Analytical School and Hermeneutics Critics of the law.

KEYWORDS: Procedural Instrumentalism, Reasoning, Proportionality, Consistency, Integrity.

\section{Introdução;}

O paradigma instrumentalista do processo civil demonstra uma progressiva caminhada rumo à ampliação das medidas assecuratórias do juiz para a efetivação da tutela jurisdicional. Atualmente, com o advento do novo Código de Processo Civil, o inciso IV, do artigo 139 autoriza ao magistrado "determinar todas as medidas indutivas, coercitivas, mandamentais ou sub-rogatórias necessárias para assegurar o cumprimento de ordem judicial, inclusive nas ações que tenham por objeto prestação pecuniária”.

Tal dispositivo, entretanto, não dá ao juiz-intérprete uma carta branca para agir conforme-sua-consciência e passar por cima dos direitos fundamentais constitucionalmente garantidos. Acreditamos que o artigo 139, inciso IV possui alta carga de responsabilidade política, que só pode ser aliviada mediante uma fundamentação que leve a sério o texto constitucional/legal: o que chamamos de (b)ônus argumentativo do juiz.

Este artigo pretendeu explorar como dois dos maiores horizontes teóricojurídicos da atualidade - a Escola Analítica e a Crítica Hermenêutica do Direito enfrentam o desafio de viabilizar o (b)ônus argumentativo do magistrado na aplicação das medidas assecuratórias da tutela jurisdicional, via método dedutivo, com vistas à um instrumentalismo processual constitucionalmente adequado.

Na primeira parte, se fez um breve histórico das medidas assecuratórias do juiz no processualismo brasileiro, demonstrando como da preferência à tutela genérica ou em 
Revista Eletrônica de Direito Processual - REDP.

Rio de Janeiro. Ano 11. Volume 18. Número 2. Maio a Agosto de 2017

Periódico Quadrimestral da Pós-Graduação Stricto Sensu em Direito Processual da UERJ

Patrono: José Carlos Barbosa Moreira. ISSN 1982-7636. pp. 219-244

www.redp.uerj.br

pecúnia se passou à preferência pela tutela específica - mormente sob a influência do instrumentalismo processual.

Em seguida, passou-se à importância da fundamentação a partir do advento da CFRB, que elencou na principiologia constitucional da Jurisdição o princípio da fundamentação das decisões no inciso IX, do artigo 93, confirmada pelo artigo 10 e 489 do novo CPC/2016. Defendeu-se que tais preceitos informam uma virada paradigmática no processo civil, a qual não deixa mais espaço para o juiz paleopositivista, que julga conforme-sua-consciência ou conforme a letra da lei. Demonstrou-se que da Escola Analítica à Crítica Hermenêutica do Direito - ambas correntes autenticamente póspositivistas - abandona-se esse dilema (típico da relação sujeito-objeto), que dá lugar a um contexto de intersubjetividade.

Explorou-se como a Escola Analítica e a Crítica Hermenêutica do Direito respondem - cada uma a seu modo - à questão 'o que é norma jurídica?', e quais ferramentas dão para o enfrentamento da fundamentação da aplicação do inciso IV, do artigo 139: para a Escola Analítica, a proporcionalidade (dentre outros postulados semelhantes); para a Crítica Hermenêutica do Direito, os conceitos de integridade e coerência.

Por fim, esboçou-se a relevância da superação do pensamento (paleo)positivista no processualismo brasileiro, que deve abandonar o dogma do monopólio interpretativo da norma jurídica pelo juiz e adotar a perspectiva de uma sociedade aberta de intérpretes do Direito - com escopo em Peter Haberle -, empreitada que tanto a Escola Analítica quanto a Crítica Hermenêutica do Direito ajudam a resolver.

Só assim se poderá compreender exatamente o sentido do inciso IV, do artigo 139, no contexto de tutela dos direitos fundamentais.

\section{O paradigma instrumental do Processo e poderes do Estado-juiz}

A atividade executiva da jurisdição no processo civil já foi conceituada como sendo um conjunto de atos da autoridade por meio do qual, com ou sem concurso da 
Revista Eletrônica de Direito Processual - REDP.

Rio de Janeiro. Ano 11. Volume 18. Número 2. Maio a Agosto de 2017

Periódico Quadrimestral da Pós-Graduação Stricto Sensu em Direito Processual da UERJ

Patrono: José Carlos Barbosa Moreira. ISSN 1982-7636. pp. 219-244

www.redp.uerj.br

vontade do devedor, invade-se seu patrimônio para, à custa dele, realizar-se o resultado prático desejado concretamente pelo direito objetivo material ${ }^{2}$.

Esta definição, hoje óbvia, deve sua existência à fundação moderna da ciência processual, que tem suas origens na doutrina alemã da ação no séc. XIX, principalmente em Oskar von Bulow e sua obra Die Lehre von den processeinreden und die Processvoraussetzungen, que consolidaram de vez a separação entre direito material e processo, caracterizando o último como uma relação jurídica de Direito Público cuja validade não está à disposição das partes, mas sob a autoridade do Estado-juiz ${ }^{3}$. A partir deste marco, então, tem-se o juiz como 'senhor do processo', algo perfeitamente ilustrado na posição elevada que ocupa na concepção triangular da teoria processual ${ }^{4}$.

Apesar disso, a lógica do ordenamento jurídico brasileiro sempre prestigiou o tipo de tutela genérica (equivalente em pecúnia), por uma opção eminentemente política, justificada pelo predomínio do pensamento liberal no Brasil. A única exceção a esta tradição foi o Código de Processo de 1939, reflexo de um Estado dito assistencialista e populista, e, dessa forma, a favor de juiz ativo que representasse, no processo, o próprio Estado na busca pela justiça em prol da sociedade. O período da ditadura militar construiu o Código de Processo Civil de 1973 que contemplava o juiz como um instrumento do processo neutro e indiferente à sociedade ${ }^{5}$.

A solução oferecida pelo direito pátrio diante do descumprimento de uma obrigação sempre foi a sua conversão em perdas e danos. Isto era facilmente explicado em função do contexto liberal-individualista que se vivia, no qual predominavam os

2DINAMARCO, Cândido Rangel. Execução civil. 5. ed. São Paulo: Malheiros, 1997, p. 115.

3BÜLOW, Oskar Von. La Teoria das Excepciones Procesales y Presupuestos Procesales. Buenos Aires: EJEA, 1964, p. 293.

4CHIOVENDA, Giuseppe. Instituições de direito processual civil. Vol. I. Trad. Paolo Capitanio. Campinas/SP: Ed. Bookseller. 2 ed. 2000; CINTRA, Antonio Carlos de Araújo; GRINOVER, Ada Pellegrini; DINAMARCO, Cândido Rangel. Teoria geral do processo. 29 ed. São Paulo: Ed. Malheiros. 2013; COUTURE, Eduardo J. Introdução ao estudo do processo civil. 3 ed. Rio de Janeiro: Ed. Konfino. 1951.

5RAATZ, Igor; SANTANNA, Gustavo da Silva. Elementos da história do processo civil brasileiro: do Código de 1939 ao Código de 1973. Revista Justiça e História, v. 09, n. 17-18, 2012. 
Revista Eletrônica de Direito Processual - REDP.

Rio de Janeiro. Ano 11. Volume 18. Número 2. Maio a Agosto de 2017

Periódico Quadrimestral da Pós-Graduação Stricto Sensu em Direito Processual da UERJ

Patrono: José Carlos Barbosa Moreira. ISSN 1982-7636. pp. 219-244

www.redp.uerj.br

direitos de conteúdo patrimonial e a influência do dogma da intangibilidade da vontade humana vigorava em absoluto no âmbito do processo.

Assim, mesmo correndo o risco de concluir uma análise demasiadamente sintética, é possível afirmar que o processo civil brasileiro historicamente se mostrou indiferente à tutela específica, marcando-se como essencialmente escrito, formalista e conduzido sob o regime do princípio dispositivo ${ }^{6}$.

A referida solução-padrão, entretanto, começa a entrar em crise a partir da primeira metade do séc. XX. É que as ondas renovatórias de acesso à ordem jurídica justa e de proteção a direitos transindividuais revelaram a insuficiência da tutela pecuniária que se conhecia, o que Luiz Fux retratou como crise da condenação. Por outro lado, a aproximação do sistema jurídico brasileiro ao do commom law norte-americano, no qual os juízes detêm poderes diversos para ordenar que se faça ou deixe de fazer algo (injunctions), contribuiu para o desinteresse pelo modelo de conversão em perdas e danos $^{7}$. Neste sentido a crítica de Marinoni e Arenhart:

$\mathrm{Na}$ realidade, o modelo executivo original do Código não era apenas impotente para viabilizar a tutela ressarcitória na forma específica, mas também incapaz de permitir a obtenção das tutelas inibitória e de remoção do ilícito. Ou melhor, a técnica processual executiva, posta originariamente no Código de Processo Civil, não foi feita para viabilizar a tutela específica dos direitos, mas apenas para permitir o

6 NUNES, Dierle José Coelho. Comparticipação e policentrismo: horizontes para a democratização processual civil. 2008. Tese (Doutorado) - Pontifícia Universidade Católica de Minas Gerais, Programa de Pós-Graduação em Direito.

7 "À semelhança do que fizera com as condenações de entrega de coisa e das obrigações de fazer e não fazer, o legislador [na reforma de 2005] emprestou o caráter autoexecutável às condenações por quantia certa contra devedor solvente, de sorte que a realização prática da sentença passou a se operar em continuação à relação de cognição, permitindo, interinalmente, as discussões sobre fatos supervenientes influentes nessa verdadeira execução do julgado, quer quanto aos aspectos formais quer quanto aos aspectos materiais inerentes à obrigação em si, como, v. g., uma transação posterior a uma compensação, um pagamento noticiado a posteriori etc. É inegável a influência do sistema do common law, que abandonou a figura do juiz burocrata, limitado à iurisdictio, para encerrar no magistrado a velha postura do pretor romano que nos interditos expedia ordens a serem cumpridas incontinentemente. Essa novel técnica se coaduna com a mandamentalidade das decisões judiciais, consagrada no artigo 14, V, do CPC, bem como com as suas duas reformas sucessivas referentes ao cumprimento da sentença e à execução extrajudicial" (FUX, Luiz. Teoria geral do processo civil. Rio de Janeiro: Forense, 2014, p. 337). 
Revista Eletrônica de Direito Processual - REDP.

Rio de Janeiro. Ano 11. Volume 18. Número 2. Maio a Agosto de 2017

Periódico Quadrimestral da Pós-Graduação Stricto Sensu em Direito Processual da UERJ

Patrono: José Carlos Barbosa Moreira. ISSN 1982-7636. pp. 219-244

www.redp.uerj.br

alcance da tutela ressarcitória pelo equivalente e da tutela da obrigação contratual inadimplida ${ }^{8}$.

Neste cenário de valorização da tutela específica encontra eco a lição chiovendiana posteriormente complementada por Barbosa Moreira de que o processo deve dar ao titular do direito lesionado (ou ameaçado de lesão), na medida do que for praticamente possível, tudo aquilo - e precisamente aquilo - que ele teria caso não houvesse a violação 9 .

No antigo Código de Processo Civil, esta virada paradigmática é sinalizada pelo art. $461, \S 5^{\circ}$, do atual CPC (nitidamente influenciado pelo art. 84, $\S 5^{\circ}$, do CDC), que, afastando-se do dogma da intangibilidade da vontade humana e se aproximando do que Dinamarco chamou de duplo sentido da instrumentalidade processual ${ }^{10}$, concede ao juiz poderes para se valer das medidas necessárias à efetivação da tutela específica ou do resultado prático equivalente. $\mathrm{O}$ modelo é estendido, posteriormente, também às obrigações de dar coisa distinta de dinheiro (Art. 461-A, CPC).

Passa-se a ter como atividade executiva toda e qualquer modificação sentida no mundo fenomênico que se volte à realização prática de direitos. Toda "técnica de atuação dos direitos" $"$. Merece destaque o fato de que a expressão 'tais como' presente no

8ARENHART, Sérgio Cruz; MARINONI, Luiz Guilherme. Curso de processo civil, vol. III. São Paulo: Revista dos Tribunais. 2014, p. 46.

9CHIOVENDA, Giuseppe. Dell'azione nascente dal contrato preliminare. Saggi di Diritto Processuale (1894-1937), v. I. Millano: Giuffrè, 1993, p. 110; MOREIRA, José Carlos Barbosa. Notas sobre o problema da "efetividade" do processo. Temas de direito processual. $3^{\text {a }}$ série. São Paulo: Saraiva, 1984, p. 28.

10 "Para isso, em primeiro lugar, é indispensável que o sistema esteja preparado para produzir decisões capazes de propiciar a tutela mais ampla possível aos titulares de direitos reconhecidos pelo juiz (e, aqui, é inevitável a superposição do discurso acerca da utilidade e efetividade das decisões, ao da abertura da via de acesso). Onde for possível produzir precisamente a mesma situação que existiria se a lei não fosse descumprida, que sejam proferidas decisões nesse sentido e não outras meramente paliativas. [...] $\mathrm{O}$ desenvolvimento das ideias a respeito incluiu também, consequentemente, repúdio à facilidade com que tradicionalmente se apontava a conversão em pecúnia como solução para obrigações de fazer não cumpridas. [...] Na linha desse pensamento, a Reforma de 1994 acresceu grandes poderes ao juiz, no processo de conhecimento, com vista a levar o obrigado a adimplir as obrigações de fazer ou de não-fazer, sem necessidade da execução forçada" (DINAMARCO, Cândido Rangel. A instrumentalidade do processo. 14 ed. São Paulo: Ed. Malheiros. 2009, p. 352-353).

11CHIARLONI, Sergio, Ars distinguendi e tecniche di attuazione dei diritti. Salvatore Mazzamuto (Org.). Processo e tecniche de atuazione deidiritti. v. I. Napole: Jovene, 1989, p. 184. 
Revista Eletrônica de Direito Processual - REDP.

Rio de Janeiro. Ano 11. Volume 18. Número 2. Maio a Agosto de 2017

Periódico Quadrimestral da Pós-Graduação Stricto Sensu em Direito Processual da UERJ

Patrono: José Carlos Barbosa Moreira. ISSN 1982-7636. pp. 219-244

www.redp.uerj.br

parágrafo $5^{\circ}$ do artigo 461 do $\mathrm{CPC} / 73^{12}$ indicava o caráter meramente exemplificativo das

medidas executivas disponíveis ao juiz, permitindo a este, portanto, eleger livremente "além das medidas de apoio enumeradas, qualquer outra que seja adequada, suficiente e proporcional para obtenção da tutela específica" ${ }^{13}$.

O perfil da atividade executiva no antigo Código de Processo Civil brasileiro é estruturado a partir de dois critérios: a) o tipo de obrigação: fazer/não fazer, pagar soma em dinheiro ou entregar coisa diversa de dinheiro; b) o local em que a obrigação foi reconhecida: pronunciamento judicial ou título executivo extrajudicial.

Embora tradicionalmente só se considerasse execução os meios sub-rogatórios, os poderes - os mecanismos - executórios coercitivos podiam ser subdivididos em poderes coercitivos (restrição de direitos e poderes de coerção patrimonial) e poderes e meios executórios sub-rogatórios - poderes de desapossamento, de transformação e de expropriação ${ }^{14}$.

Ou seja, desde antes do CPC/2015, o ordenamento jurídico-processual pátrio já municiava o magistrado com poderes atípicos (ou inominados), posições jurídicas subjetivas que, a despeito de não estarem previamente descritas em lei, se mostrassem necessárias para atuação prática do direito material em crise.

O novo Código de Processo Civil não deixa margem dúvida quanto à legalidade da atipicidade das medidas executivas ao conferir ao magistrado o poder de "determinar todas as medidas indutivas, coercitivas, mandamentais ou sub-rogatórias necessárias para

12 "§ 5o Para a efetivação da tutela específica ou a obtenção do resultado prático equivalente, poderá o juiz, de ofício ou a requerimento, determinar as medidas necessárias, tais como a imposição de multa por tempo de atraso, busca e apreensão, remoção de pessoas e coisas, desfazimento de obras e impedimento de atividade nociva, se necessário com requisição de força policial."

13GAJARDONI. Fernando Fonseca. Flexibilização procedimental: um novo enfoque para o estudo do procedimento em matéria processual, de acordo com as recentes reformas do CPC. São Paulo: Atlas, 2008, p. 156. Também neste sentido, segundo o autor, BUENO, Cássio Scarpinella. In: MARCATO, Antonio Carlos (Coord.). Código de Processo Civil interpretado. São Paulo: Atlas, 2004, p. 1413; THEODORO JÚNIOR, Humberto. Curso de direito processual civil, vol. III, p. 34; ABELHA, Marcelo. Manual de execução civil. Rio de Janeiro: Forense. 2006, p. 219-220; GRINOVER, Ada Pellegrini. Tutela jurisdicional nas obrigações de fazer e não fazer. In: TEIXEIRA, Sálvio de Figueiredo (Org.) Reforma do Código de Processo Civil. São Paulo: Saraiva, 1996, p. 257.

14 PINHEIRO, Paulo Eduardo d'Arce, Poderes executórios do juiz. São Paulo: Saraiva, 2011, p. 242-245. 
Revista Eletrônica de Direito Processual - REDP.

Rio de Janeiro. Ano 11. Volume 18. Número 2. Maio a Agosto de 2017

Periódico Quadrimestral da Pós-Graduação Stricto Sensu em Direito Processual da UERJ

Patrono: José Carlos Barbosa Moreira. ISSN 1982-7636. pp. 219-244

www.redp.uerj.br

assegurar o cumprimento de ordem judicial, inclusive nas ações que tenham por objeto prestação pecuniária" (Art. 139, inciso IV). Neste cenário

Ao juiz é conferido o poder geral para a adoção de medidas coercitivas. Vale dizer: providências atípicas podem ser adotadas. Ele não fica adstrito aos mecanismos expressamente previstos no ordenamento (como a multa processual). [...] O juiz, além disso, não fica vinculado às medidas que eventualmente o autor pleiteie (ainda que no caso, pelo que se tem notícia, a providência coercitiva tenha sido inclusive pleiteada pelo Ministério Público, autor da ação). As medidas em questão são adotáveis de ofício. De resto, tem-se também reconhecido que a norma em questão é subsidiariamente aplicável ao processo penal $\left(\mathrm{CPP}\right.$, art. $\left.3^{\circ}\right) .^{15}$

Neste sentido, a Enfam (Escola Nacional de Formação e Aperfeiçoamento de Magistrados) divulgou 62 enunciados aprovados por cerca de 500 magistrados durante o seminário 'O Poder Judiciário e o novo CPC', realizado no período de 26 a 28 de agosto de 2015, dentre os quais o Enunciado no 48: “O art. 139, IV, do CPC/2015 traduz um poder geral de efetivação, permitindo a aplicação de medidas atípicas para garantir o cumprimento de qualquer ordem judicial, inclusive no âmbito do cumprimento de sentença e no processo de execução baseado em títulos extrajudiciais” (grifo nosso).

Percebe-se, então, um movimento ascendente na direção do fortalecimento da discricionariedade judicial, cuja justificativa reside na efetivação dos direitos materiais, fim último do processo civil conforme a herança instrumentalista ${ }^{16}$ de Von Bullow, agora somada à doutrina das injuctions anglo-saxã, cujos antecedentes são os interditos romanos e as ordens reais ou writs da antiga Chancelaria inglesa responsáveis pela correção das omissões e defeitos da lei comum ${ }^{17}$.

15TALAMINI, Eduardo. Medidas judiciais coercitivas e proporcionalidade: a propósito do bloqueio do whatsapp por 48 horas (em 17.12.15). Informativo Justen, Pereira, Oliveira e Talamini, Curitiba, $\mathrm{n}^{\mathrm{o}}$ 106, dezembro de 2015, disponível em http://www.justen.com.br/informativo, acesso em 12.09.2016.

16 "A visão instrumentalista do processo é nitidamente dependente de um sujeito cognoscente [...]. $\mathrm{O}$ processo "depende", pois, da capacidade intelectiva/intuitiva do juiz, que carrega assim, sobseus ombros, o peso da subjetividade do sujeito da modernidade". (STRECK, Lenio Luiz. Hermenêutica jurídica e(m) crise: uma exploração hermenêutica da construção do Direito. 8.ed. Porto Alegre: Livraria do Advogado, 2009, p. 262-263).

17 RAACK, David W. (1986) "A History of Injunctions in England Before 1700," Indiana Law Journal: Vol. 61 : Iss. 4, Article 1. 1986. Available at: http://www.repository.law.indiana.edu/ilj/vol61/iss4/1. 
Revista Eletrônica de Direito Processual - REDP.

Rio de Janeiro. Ano 11. Volume 18. Número 2. Maio a Agosto de 2017

Periódico Quadrimestral da Pós-Graduação Stricto Sensu em Direito Processual da UERJ

Patrono: José Carlos Barbosa Moreira. ISSN 1982-7636. pp. 219-244

www.redp.uerj.br

Ocorre que "onde a discricionariedade começa, aí o Direito termina", parafraseando Kenneth Culp Davis ${ }^{18}$. Partimos da premissa de que a parcela constituinte do 'bloco nomoestático' da Constituição brasileira, isto é, a dimensão substancial de validade do Direito moderno, impede a construção de sua legitimidade tão somente sob a autoridade do aparato estatal ${ }^{19}$, e lega à teoria do Direito contemporânea o desenvolvimento de uma teoria da interpretação/aplicação/decisão judicial constitucionalmente adequadas.

\section{Constitucionalismo democrático e dever de fundamentação}

Mesmo considerando que é facilmente identificável a outorga de poderes aos juízes para que estes efetivem os direitos positivados, é também possível afirmar que a partir do advento da CFRB, que elencou na principiologia constitucional da Jurisdição o princípio da fundamentação das decisões - inciso IX, artigo 93 - "não há mais espaço para o juiz exegeta, paleopositivista e burocrata, fiel seguidor do senso comum teórico dos juristas" ${ }^{\prime 20}$.

Nada menos que isso significa o texto do segundo inciso do artigo 489, que elenca a fundamentação como elemento essencial da sentença, aliado ao parágrafo primeiro do mesmo artigo. ${ }^{21}$

A título de reforço, destacam-se ainda o parágrafo $2^{\circ}$ do artigo 489, que determina ao juiz que justifique o objeto, os critérios gerais, as razões e premissas fáticas

18 DAVIS, Kenneth Culp. Discretionary Justice: a preliminary inquiry, ouisiana: Louisiana University, Press, 1977. n. I, p. 3.

19 FERRAJOLI, Luigi. Principia juris. Teoria del Diritto. Roma/Bari: Laterza, 2007, t. 1, p. 40.

20 LOPES JR. Aury. Introdução crítica ao processo penal: fundamentos da instrumentalidade garantista. 3 ed. Rio de Janeiro: Lumen Juris, 2005, p. 283.

$21 \S 1$ o Não se considera fundamentada qualquer decisão judicial, seja ela interlocutória, sentença ou acórdão, que: I - se limitar à indicação, à reprodução ou à paráfrase de ato normativo, sem explicar sua relação com a causa ou a questão decidida; II - empregar conceitos jurídicos indeterminados, sem explicar o motivo concreto de sua incidência no caso; III - invocar motivos que se prestariam a justificar qualquer outra decisão; IV - não enfrentar todos os argumentos deduzidos no processo capazes de, em tese, infirmar a conclusão adotada pelo julgador; V - se limitar a invocar precedente ou enunciado de súmula, sem identificar seus fundamentos determinantes nem demonstrar que o caso sob julgamento se ajusta àqueles fundamentos; VI - deixar de seguir enunciado de súmula, jurisprudência ou precedente invocado pela parte, sem demonstrar a existência de distinção no caso em julgamento ou a superação do entendimento. 
Revista Eletrônica de Direito Processual - REDP.

Rio de Janeiro. Ano 11. Volume 18. Número 2. Maio a Agosto de 2017

Periódico Quadrimestral da Pós-Graduação Stricto Sensu em Direito Processual da UERJ

Patrono: José Carlos Barbosa Moreira. ISSN 1982-7636. pp. 219-244

www.redp.uerj.br

que fundamenta a ponderação efetuada no caso de colisão entre normas; o artigo 926, por seu turno, que impõe aos tribunais o dever de uniformizar sua jurisprudência e mantê-la estável, íntegra e coerente; e por último os artigos 10 e 11, os quais impedem a 'decisão surpresa' - com base em fundamento a respeito do qual não se tenha dado às partes oportunidade de se manifestar - e reforçam a necessidade de fundamentação do julgamento, em homenagem ao inciso IX, do artigo 93, CFRB ${ }^{22}$.

Conclui-se que é impossível cogitar, após a Constituição Federal de 1988, um processo civil pela perspectiva dogmática e técnica, preocupada exclusivamente com a busca da eficiência, sem tomar por base o modelo constitucional do processo, no qual a decisão judicial visa a participação e legitimidade de todos os envolvidos ${ }^{23}$.

O modelo processual de von Bulow merece revisão, justamente no ponto em que resiste ao modelo constitucional do processo: no protagonismo judicial que advoga, condutor do juiz solitário e do esvaziamento do papel constitucional do processo ${ }^{24}$. Neste sentido é que "[...] a motivação serve para o controle da racionalidade da decisão judicial" 25 . A fundamentação da decisão judicial, antes que prolixa, deve dizer respeito ao caso concreto, estruturar-se em conceitos e critérios claros e dialogar com todos os argumentos levantados pelas partes em suas manifestações ${ }^{26}$.

Estamos diante, portanto, de uma virada paradigmática no processo civil, que encontra eco nos horizontes teóricos - berços para as teorias do direito - mais diversos. Da democracia deliberativa habermasiana - que advém da Escola Analítica da filosofia da linguagem e desemboca numa analítica do discurso jurídico, aproveitada por Alexy -

22 Não sem razão Luiz Guilherme Marinoni afirma que "Sem motivação a decisão judicial perde duas características centrais: a justificação da norma jurisdicional para ocaso concreto e a capacidade de orientação de condutas sociais. Perde, em uma palavra, o seu próprio caráter jurisdicional" (MARINONI; Luiz Guilherme; ARENHART, Sergio Cruz; MITIDIERO, Daniel. Novo código de processo civil comentado. $1^{a}$ ed. São Paulo: Ed. Revista dos Tribunais. 2015, p. 110).

23NUNES, Dierle (et al.). Curso de direito processual civil: fundamentação e aplicação. Belo Horizonte: Ed. Fórum, 2011, p. 21.

24NUNES, Dierle (et al.). Curso de direito processual civil: fundamentação e aplicação. Belo Horizonte: Ed. Fórum, 2011, p. 37.

25 LOPES JR. Aury. Introdução crítica ao processo penal: fundamentos da instrumentalidade garantista. 3 ed. Rio de Janeiro: Lumen Juris, 2005, p. 259.

26MARINONI; Luiz Guilherme; ARENHART, Sergio Cruz; MITIDIERO, Daniel. Novo código de processo civil comentado. $1^{a}$ ed. São Paulo: Ed. Revista dos Tribunais. 2015, p. 492. 
Revista Eletrônica de Direito Processual - REDP.

Rio de Janeiro. Ano 11. Volume 18. Número 2. Maio a Agosto de 2017

Periódico Quadrimestral da Pós-Graduação Stricto Sensu em Direito Processual da UERJ

Patrono: José Carlos Barbosa Moreira. ISSN 1982-7636. pp. 219-244

www.redp.uerj.br

ao constitucionalismo de Dworkin - que pressupõe o caráter interpretativo do direito e com Gadamer e Streck fornece a possibilidade de uma Crítica Hermenêutica do direito, existe um ponto comum: a tentativa de superar o sujeito solipsista na teoria/práxis do direito $^{27}$.

Precisamente na tentativa de especificar condutas adequadas à realização do valor prestigiado pela efetividade que o legislador positivou a regra do $\S 5^{\circ}$ do art. 461 do antigo CPC, nos seguintes termos: "para a efetivação da tutela específica ou a obtenção do resultado prático equivalente, poderá o juiz, de ofício ou a requerimento, determinar as medidas necessárias, tais como a imposição de multa por tempo de atraso, busca e apreensão, remoção de pessoas e coisas, desfazimento de obras e impedimento de atividade nociva, se necessário com requisição de força policial".

Estávamos ante um rol meramente exemplificativo. O juiz sequer estava vinculado às medidas eventualmente pleiteadas pelo autor. Tal quadro, porém, não legitimava poderes executórios ilimitados ${ }^{28}$. Atualmente, o inciso IV do artigo 139 expressa a opção do processualismo contemporâneo de abrir mão do rol exemplificativo anteriormente adotado, substituindo-o por uma cláusula geral de efetivação.

A atividade decisória de cumprimento de medidas ganha uma nova perspectiva que possibilita o (re)dimensionamento das determinações judiciais direcionadas a

27Neste sentido, defende que a dogmática do Código de Processo Civil de 2015 absorva a legitimação pela compreensão hermenêutica e os critérios de justificação analítica, ambos voltados a combater a discricionariedade judicial (ZANETI JR. Hermes; PEREIRA, Carlos Frederico Bastos. Teoria da decisão judicial no Código de Processo Civil: uma ponte entre hermenêutica e analítica?. In: Revista de Processo. Ano 41. vol. 259. setembro/2016. pp. 21-54).

28 Conforme lição de Barbosa Moreira "o juiz não se limita a utilizar normas pré-fabricadas, mas desempenha aí uma função criadora, é coisa de que ninguém mais duvida. $\mathrm{O}$ juiz simples boca da lei, sonhado por antiga doutrina, se alguma vez existiu, é defunto de longa data sepultado. Há limites, contudo, para semelhante criação. O juiz cria nos interstícios da rede normativa; não se lhe permite sobrepor a ela sua fantasia, sorvida que seja nas fontes mais puras e alimentada pelas mais santas intenções. Falece ao juiz legitimação política para irrogar-se com amplitude o papel de legislador" (MOREIRA, José Carlos Barbosa. Notas sobre o problema da "efetividade" do processo. Temas de direito processual. $3^{\text {a }}$ série. São Paulo: Saraiva, 1984, p. 60). 
Revista Eletrônica de Direito Processual - REDP.

Rio de Janeiro. Ano 11. Volume 18. Número 2. Maio a Agosto de 2017

Periódico Quadrimestral da Pós-Graduação Stricto Sensu em Direito Processual da UERJ

Patrono: José Carlos Barbosa Moreira. ISSN 1982-7636. pp. 219-244

www.redp.uerj.br

implementação de direitos positivos e a promoção de reformas estruturais. Sincretizam-se cognição e execução com vistas a uma nova racionalidade processual ${ }^{29}$.

Isso, porém, não significa que se legitima, agora, um ativismo judicial solipsista que não respeita os direitos individuais constitucionalmente garantidos ${ }^{30}$. Antes disso, acreditamos que o cerne do inciso IV do artigo 139 do novo CPC significa e aponta para a ampliação do âmbito de responsabilidade do juiz neste novo modelo de racionalidade cognitiva-executiva.

Acredita-se que com o novo CPC tal cláusula geral de efetivação pressupõe necessariamente um (b)ônus argumentativo dado ao juiz que se valerá dela, mormente tendo em conta a determinação do inciso II, $\S 1^{\circ}$, artigo 489. Neste sentido, para evitar a busca superficial e utilitarista por resultados inconstitucionais, urge que se debatamos as bases teóricas da liberdade de julgar.

Analisemos quais ferramentas de teoria da decisão judicial estes horizontes apresentam.

\subsection{Proporcionalidade}

29 "Como já constatava Fiss (FISS, Owen. Fiss, The Forms of Justice. Harvard Law Review. v. 93. Nov./ 1979. p. 02), a jurisdição quando é instada a promover reformas estruturais (mediante uma litigância de interesse público (para, por exemplo, promover dessegregação entre brancos e negros, implementação de direitos sociais, ou mesmo obrigações patrimoniais etc.) deve fundamentar a decisão de modo a viabilizar, mediante um contraditório mais abrangente, uma decisão fundamentada com a preocupação com o modo de sua execução e com uma postura de humildade em face da complexidade da situação de aplicação, decorrente da diversidade de interesses envolvidos e do aumento dos afetados (inclusive com o reforço da importância dos amici curiae)". www.conjur.com.br/2016-ago-25/senso-incomum-interpretar-art-139-ivcpc-carta-branca-arbitrio.

30"A propósito, sobre algumas das medidas de restrição de direitos que têm sido perigosamente cogitadas, vale lembrar aqui do dramático HC 45.232, julgado em 21/2/1968, rel. min. Themístocles Cavalcanti, quando o Supremo Tribunal Federal teve que dizer inconstitucional, em plena ditadura, o artigo 48 da Lei de Segurança Nacional, pelo qual o simples recebimento da denúncia ou a prisão em flagrante importava a suspensão do exercício de profissão do emprego público ou privado. Basta ler o acórdão para ver a perigosa similitude com algumas medidas que estão sendo cogitadas para implementar o artigo 139, IV do CPC. Afinal, ao que lemos, o devedor, ao não pagar, poderia inclusive perder a CNH ou seu passaporte. Ou ser proibido de prestar concurso público. Ou, ainda, outras restrições inconstitucionais." (STRECK, Lenio Luiz. Como interpretar o artigo 139, IV, do CPC? Carta branca para o arbítrio?. disponível em: www.conjur.com.br/2016-ago-25/senso-incomum-interpretar-art-139-iv-cpc-carta-branca-arbitrio. acesso em 23.09.2016). 
Revista Eletrônica de Direito Processual - REDP.

Rio de Janeiro. Ano 11. Volume 18. Número 2. Maio a Agosto de 2017

Periódico Quadrimestral da Pós-Graduação Stricto Sensu em Direito Processual da UERJ

Patrono: José Carlos Barbosa Moreira. ISSN 1982-7636. pp. 219-244

www.redp.uerj.br

A Escola Analítica do direito supera a diferença ontológica entre o que é texto de

lei e o que é norma jurídica através da catalogação de norma jurídica como gênero que comporta três espécies: princípios (um ideal a ser alcançado), regras (um comportamento a ser seguido) e postulados normativos (organizadores e estruturantes da aplicação das demais normas) ${ }^{31}$.

O mesmo signo pode revestir-se demais de uma espécie normativa. A igualdade preceituada no caput do artigo $5^{\circ}$ da CFRB, por exemplo, pode funcionar como princípio, regra ou mesmo postulado normativo aplicativo ${ }^{32}$, para a Escola Analítica do Direito.

Foquemos na espécie postulado normativo desta vertente: a proporcionalidade, tendo em conta que o trabalho se situa ao nível da teoria da decisão judicial.

Comumente chamada de princípio, a proporcionalidade ostenta estrutura e

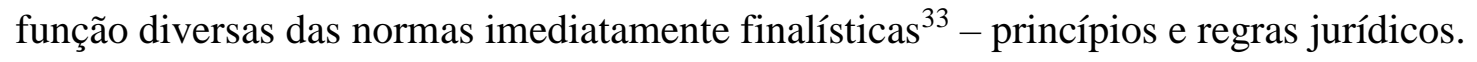

A racionalização do uso da proporcionalidade constitui a verificação de três submáximas, testes ou exigências $^{34}$ : i) adequação: o meio escolhido deve ser apto a promover o resultado pretendido; ii) necessidade: o meio utilizado, dentre os igualmente eficazes, deve ser o menos restritivo (oneroso) possível; iii) proporcionalidade em sentido

\footnotetext{
31A obra de referência aqui é de Humberto Ávila (Teoria dos princípios. 8. ed. São Paulo: Malheiros, 2008). De mais a mais, certo é que destrinchar cada uma das construções teóricas envolvendo a distinção entre princípios e regras significaria inconveniente desvio metodológico. Assim, sobre as discussões envolvendo o tema, vale a pena conferir também as obras de Ronald Dworkin (I diritti presi sul serio. Bolonha: Il Mulino, 1982), Robert Alexy (Teoria dos direitos fundamentais. São Paulo: Malheiros, 2008) e, no Brasil, Virgílio Afonso da Silva (Princípios e regras: mitos e equívocos acera de uma distinção, Revista Latino-Americana de Estudos Constitucionais, n. 1, Belo Horizonte: DelRey, jan./jul., 2003, pp. 612-615). 32Paulo Eduardo d'Arce Pinheiro, Poderes executórios do juiz. São Paulo: Saraiva, 2011, pp.182-184.

33ÁVILA, Humberto. Teoria dos princípios. 8. ed. São Paulo: Malheiros, 2008, pp. 71-78.

34 Este pensamento foi estruturado a partir das ideias lançadas por Humberto Ávila, em seu O que é “devido processo legal”? Revista de processo, v. 33, n. 163. São Paulo: RT, set. 2008, pp. 51-52. Neste texto, o autor constrói semelhante raciocínio tendo como base o princípio do devido processo legal. Em sua metáfora, "o dever de adequação está para um princípio assim como a sombra está para o objeto que se interpõe entre o sol e o chão. Separar o dever de adequação do princípio que deve ser adequadamente promovido é separar a sombra do objeto que ela projeta. O mesmo vale para os deveres de necessidade e proporcionalidade: eles não são conteúdos normativos independentes a serem realizados, mas deveres implicados na sua própria positivação e que, por mais paradoxal que possa parecer, estruturam a própria realização dos princípios".
} 
Revista Eletrônica de Direito Processual - REDP.

Rio de Janeiro. Ano 11. Volume 18. Número 2. Maio a Agosto de 2017

Periódico Quadrimestral da Pós-Graduação Stricto Sensu em Direito Processual da UERJ

Patrono: José Carlos Barbosa Moreira. ISSN 1982-7636. pp. 219-244

www.redp.uerj.br

estrito: o fim objetivado pela medida estatal supera as desvantagens da intervenção no direito fundamental ${ }^{35}$.

Tais observações precedentes demonstram alguns parâmetros materiais a respeito da cláusula geral de atipicidade executiva. Acontece que, além desses parâmetros atinente ao conteúdo, a legitimidade da medida executiva eleita perpassa balizas de índole procedimental ${ }^{36}$.

A vagueza conceitual e sistemática desse parâmetro ao tempo em que revela a insuficiência do modelo impõe o esquadrinhamento de critérios normativos seguros. Todas essas considerações conduzem à conclusão de que a expressão "medidas necessárias", contida no $\S 5^{\circ}$ do art. 461 do antigo CPC e no inciso IV, do artigo 139, do atual Código e que embasa o poder geral de efetivação da tutela jurisdicional, guarda, em si, uma via de mão-dupla.

Neste sentido, a proporcionalidade se volta tanto para otimização (e potencialização) dos poderes executórios do juiz, no sentido de atingir o resultado prático desejado pelo credor, quanto ao controle de legitimidade de tais decisões.

De todo modo, é certo que a instituição de uma cláusula geral executiva pelo inciso IV, do artigo 139, do novo CPC deve ser compensada por uma maior carga argumentativa da decisão definidora do mecanismo atípico, sem descuidar-se, ainda, da recorribilidade inafastável que comportam tais pronunciamentos judiciais. O problema da fundamentação adequada ganha contornos dramáticos na medida em que o recurso à proporcionalidade vem sendo feito, não raramente, com caráter meramente retórico.

\subsection{Integridade e Coerência}

35SILVA, Virgílio Afonso da. O proporcional e o razoável, Revistados Tribunais, n. 798, p. 31. Carlos Bernal Pulido (El principio de proporcionalid y los derechos fundamentales. 3. ed. Madrid: Centro de Estúdios Políticos y Constitucionales, 2007, pp. 693-696) acrescenta à adequação uma segunda faceta: medida adequada é aquela que visa a um fim constitucionalmente legítimo, sendo que uma finalidade é constitucionalmente legítima quando não está proibida, explícita ou implicitamente, na Constituição. Sobre a faceta da necessidade, em especial, cf. Karl Larenz, Metodologia da ciência do direito. Lisboa: Fundação Calouste Gulbenkian, 1989, p. 585 e seguintes.

36TALAMINI, Eduardo. Tutela relativa aos deveres de fazer e não fazer: e sua extensão aos deveres de entrega de coisa (CPC, Arts. 461 e 461-A; CDC, Art. 84). 2. ed. São Paulo: RT, 2003, p. 272. 
Revista Eletrônica de Direito Processual - REDP.

Rio de Janeiro. Ano 11. Volume 18. Número 2. Maio a Agosto de 2017

Periódico Quadrimestral da Pós-Graduação Stricto Sensu em Direito Processual da UERJ

Patrono: José Carlos Barbosa Moreira. ISSN 1982-7636. pp. 219-244

www.redp.uerj.br

A Crítica Hermenêutica do Direito propõe outra forma de enxergar o problema da contenção da discricionariedade judicial na aplicação das medidas assecuratórias. $\mathrm{O}$ problema texto/norma - que a Escola Analítica resolve ignorando a relevância do texto e focando nos diferentes tipos de normas que dele podem derivar - é resolvido pela pressuposição do caráter interpretativo do direito, que nada mais significa que a norma jurídica é a interpretação que se dá ao texto de lei.

E quando se interpreta um texto de lei? Simplesmente sempre. A Crítica Hermenêutica do Direito parte, outrossim, da Hermenêutica Filosófica que Hans-Georg Gadamer apresentou na segunda década do século XX, corrente filosófica que propõe a fusão de conceitos da hermenêutica outrora distintos como aplicação/interpretação/compreensão/uso/representação/criação/reprodução.

O Direito é, portanto, nada menos que o que se diz do Direito ${ }^{37}$. É uma teia composta de discursos entrecruzados. Uma polifonia de interpretações. E interpretar/aplicar/reproduzir/declarar o Direito, neste sentido, não é escavar a fim de encontrar o fundo verdadeiro, a essência do Direito, mas antes acrescentar mais um discurso à avalanche de discursos advindos da tradição.

A decisão jurídica, para Dworkin, não é uma questão de evidências, mas de cases, argumentos, convicções, e esta distinção, segundo o autor, demanda um novo tipo de racionalidade e de responsabilidade - daí a proposta de aproximação com a arte.

Usa-se da interpretação literária como modelo central da análise jurídica, concebendo o exercício jurisdicional de aplicação do Direito como um romance em cadeia: um empreendimento em que vários autores são responsáveis por um capítulo cada um, obedecendo a uma linha temporal pré-estabelecida, mas aleatória ${ }^{38}$.

37 “[...] a prática jurídica é um exercício de interpretação não apenas quando os juristas interpretam documentos ou leis específicas, mas de modo geral. O Direito, assim concebido, é profunda e inteiramente politico. [...] Mas o Direito não é uma questão de política pessoal ou partidária, e uma crítica do Direito que não compreenda essa diferença fornecerá uma compreensão pobre e uma orientação mais pobre ainda" (DWORKIN, Ronald. Uma questão de princípio. Tradução de Luís Carlos Borges. São Paulo: Martins Fontes, 2000, p. 217).

38Exemplo: definiu-se num jogo de dados quem e em que ordem os capítulos seriam redigidos. 
Revista Eletrônica de Direito Processual - REDP.

Rio de Janeiro. Ano 11. Volume 18. Número 2. Maio a Agosto de 2017

Periódico Quadrimestral da Pós-Graduação Stricto Sensu em Direito Processual da UERJ

Patrono: José Carlos Barbosa Moreira. ISSN 1982-7636. pp. 219-244

www.redp.uerj.br

[...] Em meu exercício imaginário, [...] espera-se que os romancistas assumam sua responsabilidade seriamente e reconheçam o dever de criar, tanto quanto puderem, um romance único, integrado, em vez de, por exemplo, uma série de contos independentes com personagens de mesmo nome. [...] Decidir casos controversos no Direito é mais ou menos como esse estranho exercício literário. [...] Cada juiz, então, é como um romancista na corrente ${ }^{39}$.

Assim como tanto a produção quanto a crítica literária têm por objetivo trazer o de mais valioso da obra de arte à tona, também a interpretação jurídica (e a interpretação da prática jurídica) deve produzir o Direito mais valioso possível. Da hermenêutica literária, então, Dworkin retira os conceitos de integridade e coerência como balizas de retenção à discricionariedade judicial (que poderia muito bem ser a do romancista em

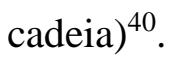

O artigo 926, do Código de Processo Civil vigente, determina que "os tribunais devem uniformizar sua jurisprudência e mantê-la estável, íntegra e coerente”, sob influência explícita da Crítica Hermenêutica do Direito. Determinar que os juízes mantenham a estabilidade, integridade e coerência de suas decisões significa vinculá-los aos dever de buscar a resposta correta, mesmo que não exista verdade absoluta; mesmo que a decisão judicial seja uma questão de $\operatorname{argumentação~} o^{41}$.

Dworkin assim exemplifica os conceitos de integridade e coerência. Ele propõe que você imagine que tem dois filhos: $\mathrm{G}$, e $\mathrm{M}$, a primeira mais velha que o segundo. $\mathrm{G}$ promete a $\mathrm{M}$ que o levaria a um show de rock no fim de semana. Acontece que G aceita

39DWORKIN, Ronald. Uma questão de princípio. Tradução de Luís Carlos Borges. São Paulo: Martins Fontes, 2000, p. 236-238.

40DWORKIN, Ronald. Uma questão de princípio. Tradução de Luís Carlos Borges. São Paulo: Martins Fontes, 2000, p. 239.

41 " [...] a Constituição não deve ser entendida como uma lista de regras isoladas e independentes, mas como uma carta de princípios que deve ser interpretada e imposta como um sistema coerente. Essa concepção da Constituição acarreta duas responsabilidades essenciais para o Judiciário. Em primeiro lugar, os juízes têm de decidir os casos particulares à luz de princípios gerais que possam ser responsavelmente associados ao texto dos artigos abstratos da Constituição, e têm de respeitar esses princípios mesmo quando as decisões por eles ditadas são controversas ou têm pouco apelo popular" (DWORKIN. Ronald. O direito da liberdade: a leitura moral da Constituição norte-americana. Trad. Marcelo Brandão Cipolla, São Paulo: Martins Fontes, 2006, p. 202). 
Revista Eletrônica de Direito Processual - REDP.

Rio de Janeiro. Ano 11. Volume 18. Número 2. Maio a Agosto de 2017

Periódico Quadrimestral da Pós-Graduação Stricto Sensu em Direito Processual da UERJ

Patrono: José Carlos Barbosa Moreira. ISSN 1982-7636. pp. 219-244

www.redp.uerj.br

sair com um colega de sala no dia de levar o irmão ao show. M vai até você para exigir que G cumpra sua promessa.

Segundo Dworkin, se você tem legitimidade para resolver a questão; como agiu em outras oportunidades; o quão a sério a história da família leva o cumprimento de promessas; que tipo de consequências se supõem caso você tome esta ou aquela decisão; e se você mudou sua opinião a respeito da importância de cumprir as promessas de última vez que um caso similar surgiu, são todas questões que envolvem a integridade e a coerência das sua decisão ao caso concreto ${ }^{42}$.

O ponto nevrálgico que define a boa ou a má interpretação da decisão é o seu grau de integridade: se leva em conta as decisões pretéritas e justifica as mudanças de interpretação dos princípios envolvidos. Isso requer a consciência dos princípios morais adotados e o esforço contínuo em seu diálogo ${ }^{43}$.

Coerente será, outrossim, a decisão que der o melhor arranjo aos diferentes princípios ou argumentos morais envolvidos na questão. A argumentação possui, aqui, mais uma vez, um papel central.

Integridade e coerência são, logo, exigências de legitimidade da aplicação/interpretação constitucional. Não eliminam os efeitos do solipsismo judicial, mas constituem uma chance para que as convicções morais dos juízes sejam trazidas à luz pela Crítica Hermenêutica do Direito, possibilitando decisões fundadas em convicções honestas e não em slogans superficiais ou metáforas batidas ${ }^{44}$.

42“[...] para que a Corte seja compreendida como uma instituição jurídica e não como mais uma câmara política, esse grande poder dos juízes - o poder de relacionar princípios de tão ampla aplicação aos artigos constitucionais abstratos - deve ser disciplinado por um respeito pela integridade das decisões desse tribunal no decorrer do tempo. [...] quando a Corte muda de ideia e afirma que errou no passado, ela perde em certa medida esse respeito; não pode fazer isso com demasiada frequência, sob pena de minar a legitimidade que lhe é dada pelo status de ser um fórum não-eleito que baseia suas decisões em princípios. Assim, a Corte deve hesitar em mudar de ideia e só deve fazê-lo quando o próprio objetivo geral da integridade de princípios exige mudança" (DWORKIN. Ronald. O direito da liberdade: a leitura moral da Constituição norte-americana. Trad. Marcelo Brandão Cipolla, São Paulo: Martins Fontes, 2006, p. 202).

43DWORKIN, Ronald. Justice for Hedgehogs. Cambridge, Massachussets: Harvard University Press. 2011, p. 101.

44DWORKIN. Ronald. O direito da liberdade: a leitura moral da Constituição norte-americana. Trad. Marcelo Brandão Cipolla, São Paulo: Martins Fontes, 2006, p. 58. 
Revista Eletrônica de Direito Processual - REDP.

Rio de Janeiro. Ano 11. Volume 18. Número 2. Maio a Agosto de 2017

Periódico Quadrimestral da Pós-Graduação Stricto Sensu em Direito Processual da UERJ

Patrono: José Carlos Barbosa Moreira. ISSN 1982-7636. pp. 219-244

www.redp.uerj.br

Por fim: é possível afirmar que de acordo com o artigo 926 o novo CPC jamais dá 'carta branca' ao juiz para que ele determine as medidas que sua consciência oferecer como aptas para que se cumpra a obrigação. Antes de abrir, baliza a liberdade interpretativa da autoridade - esse é o papel, aliás, dos princípios jurídicos.

\section{O papel constitucional do (b)ônus argumentativo - um freio à discricionariedade judicial}

As soluções apresentadas pela Escola Analítica do Direito e pela Crítica Hermenêutica do Direito possuem um nascedouro comum: são exigências da teoria da jurisdição do Segundo pós-guerra no exterior e da Constituição de 1988, no Brasil, os quais clamam por uma revisitação que coloque à prova suas bases em face dos novos desafios decorrentes do aumento das espécies e complexidade das litigiosidades e dos ganhos da teoria do direito.

Neste sentido, tanto o postulado normativo da proporcionalidade, quanto a integridade e coerência são ferramentas de análise da legitimidade da aplicação das medidas assecuratórias no processo civil.

Não é possível, portanto, que o magistrado determine a medida assecuratória que bem entender apenas invocando o inciso IV, do artigo 139, CPC.

Urge que o magistrado ("recepcionado" pela CFRB) lance mão ou da proporcionalidade, ou da integridade e coerências do texto constitucional/legal e de suas decisões pretéritas e futuras.

$\mathrm{O}$ ponto comum que se vislumbra aqui é a exigência de um (b)ônus argumentativo na aplicação das medidas assecuratórias, cuja finalidade - a despeito de suas inúmeras diferenças - é controlar a legitimidade da decisão judicial.

Parece se vislumbrar aqui uma proposta de abertura da sociedade de intérpretes da Constituição e das leis, encontrada em Peter Haberle ${ }^{45}$, por todos.

\footnotetext{
45Interpretação constitucional tem sido, até agora, conscientemente coisa de uma sociedade fechada. Dela tomam parte apenas os intérpretes jurídicos 'vinculados às corporações' [...] e aqueles participantes formais do processo constitucional. A interpretação constitucional é, em realidade, mais um elemento da sociedade
} 
Revista Eletrônica de Direito Processual - REDP.

Rio de Janeiro. Ano 11. Volume 18. Número 2. Maio a Agosto de 2017

Periódico Quadrimestral da Pós-Graduação Stricto Sensu em Direito Processual da UERJ

Patrono: José Carlos Barbosa Moreira. ISSN 1982-7636. pp. 219-244

www.redp.uerj.br

Abre-se mão, nesta quadra da história institucional do Direito, da falsa ideia de que os juízes são neutros na interpretação constitucional/legal. Segue-se o conselho de Dworkin para quem essa ideia apenas induz ao ocultamento dos motivos reais da decisão e o impedimento de uma inspeção legítima (da legitimidade) dos seus conteúdos por parte do público ${ }^{46}$.

Pressupõe-se, com a adoção de tais (b)ônus argumentativos, que o juiz não é uma consciência neutra e apartada do caso que julga, mas um ser(-aí) que se compreende a partir do mundo que lhe circunda e de sua vida cotidiana, e imprime tal compreensão em seus discursos - inclusive na interpretação do texto de lei - "Nessa medida, sempre há encobrimentos por toda parte - e sempre há também destruição de encobrimentos"47.

Também Habermas critica "o modelo de legitimidade a partir da legalidade, tal como formulado por Weber e aponta para o princípio da fundamentação"48.

A tensão entre validade (legitimidade) e facticidade (eficiência) do Direito emerge justamente de seu caráter dúplice: um pé no mundo da vida, o outro nos sistemas administrativos, o que lhe dá a posição de intermediador entre tais esferas ${ }^{49}$, encarregado de tornar compreensível nos códigos especiais da economia (dinheiro) e administração (poder) as mensagens do mundo da vida ${ }^{50}$.

aberta. Todas as potências públicas, participantes materiais do processo [de interpretação do tecido] social, estão nela envolvidas [...] (HABERLE, Peter. Hermenêutica constitucional. A sociedade aberta dos intérpretes da Constituição: contribuição para a interpretação pluralista e 'procedimental' da Constituição. Tradução: Gilmar Ferreira Mendes. Porto Alegre/RS: Sergio Antonio Fabris Editor. 2002, p. 13).

46DWORKIN, Ronald. O direito da liberdade: a leitura moral da Constituição norte-americana. Trad. Marcelo Brandão Cipolla, São Paulo: Martins Fontes, 2006, p. 57.

47GADAMER, Hans-Georg. Hermenêutica em retrospectiva, volume único. Trad. Marco Antônio Casanova. Petrópolis/RJ: Ed. Vozes. 2012, p. 75.

48NEVES, Marcelo. Do consenso ao dissenso. In: SOUZA, Jessé (Org). Democracia hoje: novos desafios para a teoria democrática contemporânea. Brasília: Editora Universidade de Brasília, 2001, Pp. 111-164, p. 118.

49NEVES, Marcelo. Do consenso ao dissenso. In: SOUZA, Jessé (Org). Democracia hoje: novos desafios para a teoria democrática contemporânea. Brasília: Editora Universidade de Brasília, 2001, Pp. 111-164, p. 113.

50NEVES, Marcelo. Do consenso ao dissenso. In: SOUZA, Jessé (Org). Democracia hoje: novos desafios para a teoria democrática contemporânea. Brasília: Editora Universidade de Brasília, 2001, Pp. 111-164, p. 118. 
Revista Eletrônica de Direito Processual - REDP.

Rio de Janeiro. Ano 11. Volume 18. Número 2. Maio a Agosto de 2017

Periódico Quadrimestral da Pós-Graduação Stricto Sensu em Direito Processual da UERJ

Patrono: José Carlos Barbosa Moreira. ISSN 1982-7636. pp. 219-244

www.redp.uerj.br

Ou seja, também em Habermas a instrumentalização do Direito precisa sempre de uma justificação moral ${ }^{51}$. Exige-se, assim, que ao paradigma instrumental do Direito processual se adicione um plus normativo que é a exigência de fundamentação da aplicação/interpretação constitucional/legal, mormente em casos de cláusulas abertas como a do inciso IV, artigo 139, CPC, e que restringem direitos fundamentais, haja vista que, retomando a proposta de Haberle, numa sociedade aberta, tais poderes do juiz só podem se desenvolver se mediados por um processo público e pluralista ${ }^{52}$.

Pressupõe-se que em tempos de constitucionalismo todas as decisões públicas devem prestar contas relativas aos princípios da CFRB. Trata-se de institucionalizar um processo de aprendizado e aprimoramento constante das decisões. Antes de diminuir ou retirar os poderes interpretativos do juiz ou a sua liberdade de julgar, almeja-se que ele se envolva mais seriamente na reconstrução das políticas públicas e na concretização dos direitos, propondo que abandone a atuação solitária e centralizada (solipsista) pela construção do resultado da decisão em conjunto, de acordo com um contexto de intersubjetividade.

No Brasil, o inciso IV do artigo 139 combinado com o artigo 190 ofertam novas possibilidades para o estudo das medidas efetivadoras. Possibilidades comparticipativas. Urge que se discutam as técnicas decisórias e processuais que visam à efetividade da jurisdição, fora dos voluntarismos autoritários.

Desta perspectiva, seria impossível, com base no artigo 139, IV do CPC/2015, ao juiz restringir unilateralmente, a partir da sua visão utilitarista, direitos individuais, pois o (b)ônus argumentativo que lhe acompanha impede sua invocação como pressuposto à medidas arbitrárias e o coloca como pressuposto para uma jurisdição comparticipativa.

51NEVES, Marcelo. Do consenso ao dissenso. In: SOUZA, Jessé (Org). Democracia hoje: novos desafios para a teoria democrática contemporânea. Brasília: Editora Universidade de Brasília, 2001, Pp. 111-164, p. 115 .

52HABERLE, Peter. Hermenêutica constitucional. A sociedade aberta dos intérpretes da Constituição: contribuição para a interpretação pluralista e 'procedimental' da Constituição. Tradução: Gilmar Ferreira Mendes. Porto Alegre/RS: Sergio Antonio Fabris Editor. 2002, p. 36. 


\section{Conclusão}

Essa breve comparação dos diferentes modos de conceber os (b)ônus argumentativos do juiz na interpretação/aplicação do inciso IV, do artigo 139, constante do CPC/2015 visou compreender essa chamada cláusula geral de efetivação como um instrumento de garantias fundamentais.

Pressupõe-se que embora o instrumentalismo de von Bulow seja uma conquista indiscutível para a teoria do processo, o Estado Democrático de Direito demanda um modo-de-julgar intersubjetivo, algo estranho a outorga de poderes ilimitados ao juiz que o instrumentalismo a-todo-custo parece defender.

Não há mais espaço para o juiz (paleo)positivista no processo judicial, que decide conforme-quer e não possui o mínimo senso de accountability com relação aos princípios constitucionais. Nada menos que isso diz o texto do artigo 926 do novo CPC, ao exigir integridade e coerência das decisões judiciais, bem como o texto do segundo inciso do artigo 489, ao elencar a fundamentação como elemento essencial da sentença, aliado ao parágrafo primeiro do mesmo artigo, que não considera fundamentada qualquer decisão judicial, seja ela interlocutória, sentença ou acórdão, que se limitar à indicação, à reprodução ou à paráfrase de ato normativo, sem explicar sua relação com a causa ou a questão decidida; empregar conceitos jurídicos indeterminados, sem explicar o motivo concreto de sua incidência no caso; invocar motivos que se prestariam a justificar qualquer outra decisão; não enfrentar todos os argumentos deduzidos no processo capazes de, em tese, infirmar a conclusão adotada pelo julgador; se limitar a invocar precedente ou enunciado de súmula, sem identificar seus fundamentos determinantes nem demonstrar que o caso sob julgamento se ajusta àqueles fundamentos.

Neste sentido, seja o postulado normativo da proporcionalidade, para a Escola Analítica; sejam os conceitos de coerência e integridade, para a Crítica Hermenêutica do Direito, são modos de se efetivar os (b)ônus argumentativos que os juízes do Estado Democrático de Direito carregam como responsabilidade política. O ponto comum que se vislumbra aqui entre estes horizontes teóricos distintos é a exigência de um (b)ônus 
Revista Eletrônica de Direito Processual - REDP.

Rio de Janeiro. Ano 11. Volume 18. Número 2. Maio a Agosto de 2017

Periódico Quadrimestral da Pós-Graduação Stricto Sensu em Direito Processual da UERJ

Patrono: José Carlos Barbosa Moreira. ISSN 1982-7636. pp. 219-244

www.redp.uerj.br

argumentativo na aplicação das medidas assecuratórias, cuja finalidade - a despeito de suas inúmeras diferenças - é controlar a legitimidade da decisão judicial.

Conforme explicado no fim do trabalho, tal exigência possui um fundo filosófico e político muito forte, que chega a - de certa forma - unir duas perspectivas teóricas quase opostas - como a Escola Analítica e a Crítica Hermenêutica. Quando o assunto é solipsismo judicial, ambas concordam: isso merece um fim.

As soluções fornecidas por elas, evidentemente, são conflitantes. Não é possível conjugar numa mesma decisão coerência, integridade e proporcionalidade. Tais conceitos pertencem a horizontes de sentido distintos.

Um exame aprofundado de como as soluções oferecidas pela Escola Analítica e pela Crítica Hermenêutica do Direito merece estudo apartado, que adote como pressupostos uma ou outra linha teórica.

É certo, entretanto, que o magistrado na democracia constitucional brasileira precisa conhecer tais ferramentas para lidar com o (b)ônus argumentativo que carrega, sob pena do perpetuamento de um constitucionalismo inacabado no Brasil.

\section{REFERÊNCIAS BIBLIOGRÁFICAS:}

ABELHA, Marcelo. Manual de execução civil. Rio de Janeiro: Forense. 2006.

ALEXY, Robert. Teoria dos direitos fundamentais. São Paulo: Malheiros, 2008.

ARENHART, Sérgio Cruz; MARINONI, Luiz Guilherme. Curso de processo civil, vol. III. São Paulo: Revista dos Tribunais. 2014.

ÁVILA, Humberto. Teoria dos princípios. 8. ed. São Paulo: Malheiros, 2008.

, O que é “devido processo legal”? Revista de processo, v. 33, n. 163. São

Paulo: RT, set. 2008, pp. 51-52.

BUENO, Cássio Scarpinella. In: MARCATO, Antonio Carlos (Coord.). Código de Processo Civil interpretado. São Paulo: Atlas, 2004.

BÜLOW, Oskar Von. La Teoria das Excepciones Procesales y Presupuestos Procesales. Buenos Aires: EJEA, 1964. 
Revista Eletrônica de Direito Processual - REDP.

Rio de Janeiro. Ano 11. Volume 18. Número 2. Maio a Agosto de 2017

Periódico Quadrimestral da Pós-Graduação Stricto Sensu em Direito Processual da UERJ

Patrono: José Carlos Barbosa Moreira. ISSN 1982-7636. pp. 219-244

www.redp.uerj.br

CHIARLONI, Sergio, Ars distinguendi e tecniche di attuazione dei diritti. Salvatore Mazzamuto (Org.). Processo e tecniche de atuazione deidiritti. v. I. Napole: Jovene, 1989.

CHIOVENDA, Giuseppe. Instituições de direito processual civil. Vol. I. Trad. Paolo Capitanio. Campinas/SP: Ed. Bookseller. 2 ed. 2000;

. Dell'azione nascente dal contrato preliminare. Saggi di Diritto Processuale (18941937), v. I. Millano: Giuffrè, 1993.

CINTRA, Antonio Carlos de Araújo; GRINOVER, Ada Pellegrini; DINAMARCO, Cândido Rangel. Teoria geral do processo. 29 ed. São Paulo: Ed. Malheiros. 2013;

COUTURE, Eduardo J. Introdução ao estudo do processo civil. 3 ed. Rio de Janeiro: Ed. Konfino. 1951

DAVIS, Kenneth Culp. Discretionary Justice: a preliminary inquiry, ouisiana: Louisiana University, Press, 1977. n. I, p. 3.

DINAMARCO, Cândido Rangel. A instrumentalidade do processo. 14 ed. São Paulo: Ed. Malheiros. 2009.

. Execução civil. 5. ed. São Paulo: Malheiros, 1997.

DWORKIN, Ronald. Justice for Hedgehogs. Cambridge, Massachussets: Harvard University Press. 2011.

, O direito da liberdade: a leitura moral da Constituição norte-americana.

Trad. Marcelo Brandão Cipolla, São Paulo: Martins Fontes, 2006.

- Uma questão de princípio. Tradução de Luís Carlos Borges. São Paulo:

Martins Fontes, 2000.

.. I diritti presi sul serio. Bolonha: Il Mulino, 1982.

FERRAJOLI, Luigi. Principia juris. Teoria del Diritto. Roma/Bari: Laterza, 2007, t. 1.

FISS, Owen. Fiss, The Forms of Justice. Harvard Law Review. v. 93. Nov/1979.

FUX, Luiz. Teoria geral do processo civil. Rio de Janeiro: Forense, 2014.

GADAMER, Hans-Georg. Hermenêutica em retrospectiva, volume único. Trad. Marco Antônio Casanova. Petrópolis/RJ: Ed. Vozes. 2012. 
Revista Eletrônica de Direito Processual - REDP.

Rio de Janeiro. Ano 11. Volume 18. Número 2. Maio a Agosto de 2017

Periódico Quadrimestral da Pós-Graduação Stricto Sensu em Direito Processual da UERJ

Patrono: José Carlos Barbosa Moreira. ISSN 1982-7636. pp. 219-244

www.redp.uerj.br

GAJARDONI. Fernando Fonseca. Flexibilização procedimental: um novo enfoque para o estudo do procedimento em matéria processual, de acordo com as recentes reformas do CPC. São Paulo: Atlas, 2008.

GRINOVER, Ada Pellegrini. Tutela jurisdicional nas obrigações de fazer e não fazer. In:

TEIXEIRA, Sálvio de Figueiredo (Org.) Reforma do Código de Processo Civil. São Paulo: Saraiva, 1996.

HABERLE, Peter. Hermenêutica constitucional. A sociedade aberta dos intérpretes da Constituição: contribuição para a interpretação pluralista e 'procedimental' da Constituição. Tradução: Gilmar Ferreira Mendes. Porto Alegre/RS: Sergio Antonio Fabris Editor. 2002

LARENZ, Karl. Metodologia da ciência do direito. Lisboa: Fundação Calouste Gulbenkian, 1989.

LOPES JR. Aury. Introdução crítica ao processo penal: fundamentos da instrumentalidade garantista. 3 ed. Rio de Janeiro: Lumen Juris, 2005.

MARINONI; Luiz Guilherme; ARENHART, Sergio Cruz; MITIDIERO, Daniel. Novo código de processo civil comentado. $1^{\mathrm{a}}$ ed. São Paulo: Ed. Revista dos Tribunais. 2015.

MOREIRA, José Carlos Barbosa. Notas sobre o problema da "efetividade" do processo. Temas de direito processual. $3^{\text {a }}$ série. São Paulo: Saraiva, 1984.

NEVES, Marcelo. Do consenso ao dissenso. In: SOUZA, Jessé (Org). Democracia hoje: novos desafios para a teoria democrática contemporânea. Brasília: Editora Universidade de Brasília, 2001, Pp. 111-164.

NUNES, Dierle (et al.). Curso de direito processual civil: fundamentação e aplicação. Belo Horizonte: Ed. Fórum, 2011.

. Comparticipação e policentrismo: horizontes para a democratizaçãoprocessual civil.

2008. Tese (Doutorado) - Pontifícia Universidade Católica de Minas Gerais, Programa de Pós-Graduação em Direito.

PINHEIRO, Paulo Eduardo d'Arce, Poderes executórios do juiz. São Paulo: Saraiva, 2011. 
Revista Eletrônica de Direito Processual - REDP.

Rio de Janeiro. Ano 11. Volume 18. Número 2. Maio a Agosto de 2017

Periódico Quadrimestral da Pós-Graduação Stricto Sensu em Direito Processual da UERJ

Patrono: José Carlos Barbosa Moreira. ISSN 1982-7636. pp. 219-244

www.redp.uerj.br

PULIDO, Carlos Bernal. El principio de proporcionalid y los derechos fundamentales. 3. ed. Madrid: Centro de Estúdios Políticos y Constitucionales, 2007, pp. 693-696.

RAACK, David W. "A History of Injunctions in England Before 1700," Indiana Law Journal: Vol. 61 : Iss. 4, Article 1. 1986. Available at: http://www.repository.law.indiana.edu/ilj/vol61/iss4/1.

RAATZ, Igor; SANTANNA, Gustavo da Silva. Elementos da história do processo civil brasileiro: do Código de 1939 ao Código de 1973. Revista Justiça e História, v. 09, n. 17$18,2012$.

SILVA, Virgílio Afonso da. O proporcional e o razoável, Revistados Tribunais, n. 798, p. 31.

SOUZA, Jessé (Org). Democracia hoje: novos desafios para a teoria democrática contemporânea. Brasília: Editora Universidade de Brasília, 2001.

SILVA, Virgílio Afonso da. Princípios e regras: mitos e equívocos acera de uma distinção, Revista Latino-Americana de Estudos Constitucionais, n. 1, Belo Horizonte: DelRey, jan./jul., 2003, pp. 612-615.

. SILVA. O proporcional e o razoável, Revistados Tribunais, n. 798. 2002.

STRECK, Lenio Luiz. Como interpretar o artigo 139, IV, do CPC? Carta branca para o arbítrio?. disponível em: www.conjur.com.br/2016-ago-25/senso-incomum-interpretarart-139-iv-cpc-carta-branca-arbitrio. acesso em 23.09.2016.

. Hermenêutica jurídica e $(m)$ crise: uma exploração hermenêutica da construção do Direito. 8.ed. Porto Alegre: Livraria do Advogado, 2009.

TALAMINI, Eduardo. Medidas judiciais coercitivas e proporcionalidade: a propósito do bloqueio do whatsapp por 48 horas (em 17.12.15). Informativo Justen, Pereira, Oliveira e Talamini, Curitiba, $\mathrm{n}^{\mathrm{o}}$ 106, dezembro de 2015, disponível em http://www.justen.com.br/informativo, acesso em 12.09.2016.

. Tutela relativa aos deveres de fazer e não fazer: e sua extensão aos deveres de entrega de coisa (CPC, Arts. 461 e 461-A; CDC, Art. 84). 2. ed. São Paulo: RT, 2003. 
Revista Eletrônica de Direito Processual - REDP.

Rio de Janeiro. Ano 11. Volume 18. Número 2. Maio a Agosto de 2017

Periódico Quadrimestral da Pós-Graduação Stricto Sensu em Direito Processual da UERJ

Patrono: José Carlos Barbosa Moreira. ISSN 1982-7636. pp. 219-244

www.redp.uerj.br

ZANETI JR. Hermes; PEREIRA, Carlos Frederico Bastos. Teoria da decisão judicial no

Código de Processo Civil: uma ponte entre hermenêutica e analítica?. In: Revista de Processo. Ano 41. vol. 259. setembro/2016. pp. 21-54. 